\title{
Physiological responses of two sublittoral nassariid gastropods to hypoxia
}

\author{
C. C. Liu ${ }^{1}$, J. M. Y. Chiu' ${ }^{2}$, L. Li ${ }^{1}$, P. K. S. Shin ${ }^{1,3}$, S. G. Cheung ${ }^{1,3, *}$ \\ ${ }^{1}$ Department of Biology and Chemistry, City University of Hong Kong, Kowloon, Hong Kong SAR \\ ${ }^{2}$ School of Biological Sciences, The University of Hong Kong, Pokfulam Road, Hong Kong SAR \\ ${ }^{3}$ State Key Laboratory of Marine Pollution, City University of Hong Kong, Kowloon, Hong Kong SAR
}

\begin{abstract}
Anthropogenic hypoxia of coastal bottom waters now affects hundreds of thousands of $\mathrm{km}^{2}$ worldwide. The present study investigated the physiological responses of 2 sublittoral nassariid gastropods, Nassarius conoidalis and N. siquijorensis, to hypoxia using endpoints, including scope for growth (SfG) and the related energy budget items (i.e. rate of energy intake from food, rate of energy lost to respiration and rate of energy lost to excretion) over a 31-d laboratory experiment. Our results showed that after exposure for $\geq 8 \mathrm{~d}$, the stronger hypoxia treatment of $1.5 \mathrm{mg} \mathrm{O}_{2} \mathrm{l}^{-1}$ significantly reduced the rate of energy intake for Nassarius siquijorensis, while $N$. conoidalis stopped feeding in the same treatment. SfG was significantly reduced in $N$. siquijorensis after exposure to $1.5 \mathrm{mg} \mathrm{O}_{2} \mathrm{l}^{-1}$ during the mid and late exposure period. Exposure to $\leq 3 \mathrm{mg} \mathrm{O} \mathrm{I}^{-1}$ also resulted in a negative SfG for $N$. conoidalis, except for the weaker hypoxia treatment during the late exposure period. Nassariid gastropods occur in great abundance in Hong Kong waters; therefore, any adverse effect on these gastropods may lead to major ecological consequences, including altered trophodynamics and disrupted nutrient recycling processes in coastal ecosystems.
\end{abstract}

KEY WORDS: Nassarius sp · Dissolved oxygen level $\cdot$ Energy budget $\cdot$ Hong Kong $\cdot$ Mortality $\cdot$ Scope for growth

\section{INTRODUCTION}

Global warming and coastal eutrophication due to ever-increasing anthropogenic activities - such as burning of fossil fuels, deforestation, sewage discharge and the use of agricultural fertilizers - are exacerbating dissolved oxygen (DO) reductions in aquatic systems (Levin 2003). When DO falls below a threshold, hypoxia occurs, resulting in the aberrant behaviour of benthic fauna, collapse of fisheries and development of dead zones (Diaz \& Rosenberg 2008). Hypoxia now affects several hundreds of thousands of $\mathrm{km}^{2}$ worldwide, and over 400 coastal systems, such as Chesapeake Bay, USA, have been designated as dead zones (Hagy et al. 2004, Diaz \& Rosenberg 2008).

While the vast majority of studies use $2 \mathrm{mg} \mathrm{O}_{2} \mathrm{l}^{-1}$ as a threshold for hypoxia, there are reports in the literature that use higher values, up to $4 \mathrm{mg} \mathrm{O}_{2} \mathrm{l}^{-1}$ (Paerl
2006). Indeed, a recent study demonstrated that the thresholds vary greatly across marine benthic organisms and that the conventional definition of $2 \mathrm{mg} \mathrm{O}_{2} \mathrm{l}^{-1}$ to designate waters as hypoxic is below the empirical sub-lethal and lethal DO thresholds for half of the species tested (Vaquer-Sunyer \& Duarte 2008).

The ecological responses to hypoxia, including mass mortality of benthos and fish, reduction of biomass and annual secondary production, are well documented and have been reviewed in the literature (Diaz \& Rosenberg 1995, 2008, Wu 2002). Hypoxia may cause changes in species abundance and distribution, and alter species community composition by eliminating sensitive species and proliferating a few, tolerant species (Dauer 1993, Weisberg et al. 2008). The trophodynamics of marine ecosystems may also be affected. Wu (1982) showed a decrease in dominance of predatory gastropods along a hypoxic gradient in 
Tolo Harbour, Hong Kong. In fact, many mobile marine organisms can actively avoid hypoxic waters (Wu 2002). Benthic fish may move to near-surface waters to breathe during reduced DO levels, and some benthic invertebrates, such as polychaetes, annelids, crustaceans and bivalves, may leave their burrows and move to the sediment surface or reduce their burial depth, making them more vulnerable to predation (Pihl et al. 1992, Nilsson \& Rosenberg 1994, Wannamaker \& Rice 2000, Wu et al. 2002).

Studies on the cellular and biochemical responses have collectively suggested that marine organisms attempt to maintain oxygen delivery and conserve energy during hypoxia by increasing respiration rate, the number of red blood cells or the oxygen binding capacity of hemoglobin, decreasing metabolic rate, down regulating protein synthesis and modifying certain regulatory enzymes (Wu 2002, 2009). Eventually, these responses and the resulting physiological adjustments may manifest themselves in growth reduction. Growth reductions have been shown in the echinoderm Amphiura filiformis, the bivalves Crassostrea virginica and Mytilus edulis (Diaz \& Rosenberg 1995), Ruditapes decussatus (Sobral \& Widdows 1997), the polychaete Capitella sp. (Forbes \& Lopez 1990) and the abalone Haliotis laevigata (Harris et al. 1999). Similarly, fish subjected to hypoxia also demonstrate growth reductions, for example, plaice Pleuronecte platessa (Petersen \& Pihl 1995), Atlantic cod Gadus morhua (Chabot \& Dutil 1999) and southern flounder Paralichthys lethostigma (Taylor \& Miller 2001).

Changes in growth often take considerable time to manifest themselves and are not discernable in shortterm studies. The scope for growth (SfG) has been used to estimate the maximum amount of energy available for growth after fulfilling essential biological processes (Genoni \& Pahi-Wohstl 1991). Previous studies have demonstrated that $\mathrm{SfG}$ is a good predictor for actual growth (Beiras et al. 1994, Baillieul et al. 1996) and, more importantly, a sensitive indicator of physiological stress in invertebrates (Maltby et al. 1990, Maltby 1992, Roast et al. 1999, Baillieul et al. 2005). The amphipods Melita longidactyla showed a reduction in SfG and other individual energy budget items (rates of energy intake from food and energy lost in respiration) when exposed to a hypoxic condition of $3.5 \mathrm{mg} \mathrm{O}_{2} \mathrm{l}^{-1}$ compared with a normal $7.5 \mathrm{mg} \mathrm{O}_{2} \mathrm{l}^{-1}$ (Wu \& Or 2005).

The neogastropod Nassariidae is one of the largest families of the Gastropoda; most of the members are presumed to be exclusively carrion scavengers (Cernohorsky 1984). Sublittoral nassariid gastropods occur in great abundance in Hong Kong waters and play an important ecological role in removing a large number of dead animals from the local sea bed (Britton \& Morton 1992, Cheung 1997, Morton \& Chan 1999). The present study investigated the physiological responses of 2 nassariid gastropods Nassarius conoidalis and $N$. siquijorensis to hypoxia using endpoints, including $\mathrm{SfG}$ and the related energy budget items (i.e. rates of energy from food intake, lost to respiration and lost to excretion) over a 31 d laboratory experiment. We hypothesized that $\mathrm{SfG}$ would be reduced during hypoxia. Note that hypoxia caused by organic pollution is often associated with elevated levels of microbially generated hydrogen sulphide (Diaz \& Rosenberg 1995, Hagy et al. 2004). While this toxic chemical in the field may also confound the hypoxic responses of animals, carefully designed laboratory experiments are appropriate to investigate the responses to DO level per se.

\section{MATERIALS AND METHODS}

Study organisms. We collected Nassarius siquijorensis and $N$. conoidalis adults by trawling at depths between 10 and $30 \mathrm{~m}$ in southern Hong Kong waters $\left(22^{\circ} 10^{\prime} \mathrm{N}, 114^{\circ} 10^{\prime} \mathrm{E}\right)$ in April 2009. Upon returning to the laboratory, the gastropods were maintained in flowing seawater at a salinity of $30 \mathrm{psu}$ at $24^{\circ} \mathrm{C}$ and were fed ad libitum with Metapenaeus ensis shrimp meat twice a week for at least 2 wk before we began the experiments (Liu \& Morton 1994).

Experimental design. Hypoxic effects were examined at $1.5,3$ and $6 \mathrm{mg} \mathrm{O} \mathrm{O}^{-1}$, corresponding to the stronger hypoxic treatment, weaker hypoxic treatment and normoxic control, respectively. Seawater in a reservoir tank, which supplied the 3 experimental chambers, was bubbled with nitrogen gas and air (Fig. 1). The flow of nitrogen gas and air were regulated by a DO controller (Cole-Parmer's 01972-00) connected to electromagnetic valves that opened or closed depending on the DO level required in the experimental chambers. The DO levels were monitored using an optical meter (TauTheta SOO-100). Seawater for the normoxic control was bubbled with air only.

The experiments were carried out with Nassarius siquijorensis and N. conoidalis separately. All treatments and replicates for one species were carried out at the same time, and each time had 9 experimental chambers $(10 \times 10 \times 12 \mathrm{~cm})$. Each DO level had 3 replicate chambers, and each chamber contained 10 gastropods and $1000 \mathrm{ml}$ seawater. The $31 \mathrm{~d}$ long experiment included: (1) acclimation period (Days 1 to 4 , gastropods of all treatments were exposed to $6 \mathrm{mg} \mathrm{O}_{2}$ $\mathrm{I}^{-1}$ ); (2) exposure period (Days 5 to 22, gastropods of different treatments were exposed to different DO levels: 1.5, 3 and $6 \mathrm{mg} \mathrm{O}_{2} \mathrm{l}^{-1}$ ); and (3) recovery period (Days 23 to 31 , all gastropods were returned to $6 \mathrm{mg} \mathrm{O}_{2} \mathrm{l}^{-1}$ ). Seawater of $30 \mathrm{psu}$ was used and maintained at $24^{\circ} \mathrm{C}$. Also, 


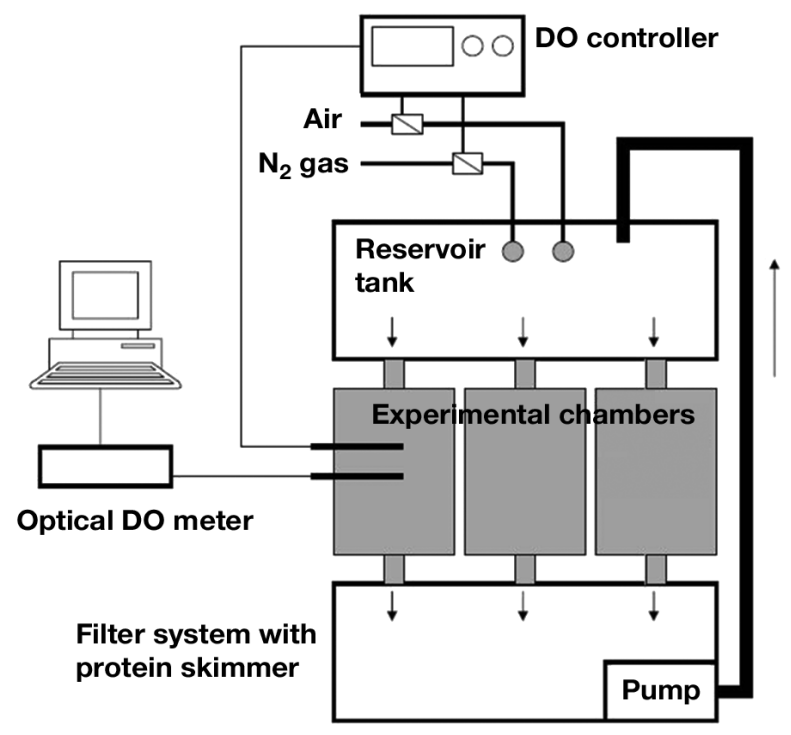

Fig. 1. Experimental setup

half of the seawater in the chambers was changed daily. Seawater was adjusted to the desired DO level prior to changing. The gastropods were fed with Metapenaeus ensis shrimp meat on Days 1, 5, 8, 12, 15, 19, 23, 26 and 29. Furthermore, all gastropods were examined every day and those that did not respond to the stimulation of a pipette tip were considered dead and removed from the experimental chambers.

Rate of energy intake from food. The rate of energy intake from food was calculated as:

Rate of energy intake from food $\left(\mathrm{J} \mathrm{h}^{-1}\right.$ ind.$\left.^{-1}\right)=$ Rate of food consumption $\left(\mathrm{g} \mathrm{h}^{-1}\right.$ ind $\left.^{-1}\right) \times$ Absorption efficiency $(\%) \times$ Calorific value $\left(\mathrm{J} \mathrm{g}^{-1}\right)$

The rate of food consumption was determined on experimental Days 1, 5, 12, 19, 23 and 29. All gastropods from an experimental chamber were transferred to a beaker with seawater adjusted for the treatment DO level and shrimp Metapenaeus ensis meat. The gastropods were satiated and stopped consuming the shrimp meat left in the beaker after $2 \mathrm{~h}$. The wet wt of the shrimp meat before and after consumption by the gastropods were measured to the nearest $0.1 \mathrm{mg}$. The wet wt $\left(\mathrm{W}_{\text {wet }}\right)$ of shrimp meat consumed was then determined and the dry wt $\left(\mathrm{W}_{\mathrm{dry}}\right)$ was calculated using a linear regression equation established in a preliminary experiment: $\mathrm{W}_{\text {dry }}=0.1929 \mathrm{~W}_{\text {wet }}-0.0277 \mathrm{n}=$ $\left.35, \mathrm{r}^{2}=0.952, \mathrm{SE}=0.046, \mathrm{p}<0.001\right)$.

Absorption efficiency was measured as follows (Conover 1966):

$$
\text { Absorption efficiency }=(F-E) /(1-E) F \times 100
$$

where $F=$ ash-free dry wt:dry wt ratio of shrimp meat, $E=$ ash-free dry wt:dry wt ratio of faeces.
The dry wt and ash-free dry wt of the shrimp meat were determined by weighing the dried shrimp meat that had been incubated in an oven at $90^{\circ} \mathrm{C}$ for $48 \mathrm{~h}$ and weighing the burned shrimp meat that had been incubated in a furnace at $450^{\circ} \mathrm{C}$ for $5 \mathrm{~h}$, respectively. Gastropod faeces were collected by a dropper from the experimental chamber after feeding and put onto a pre-weighed filter (Whatman GF/C $47 \mathrm{~mm}$ ). The faeces-loaded filter was first rinsed with distilled water to remove any salt and subsequently determined for the dry wt and ash-free dry wt using the methods described for shrimp meat.

The calorific value of shrimp meat was $20290 \mathrm{~J} \mathrm{~g}^{-1}$, as measured using oxygen bomb calorimetry (PARR1261EF).

Rate of energy lost to respiration. The rate of energy lost to respiration was measured on Days 2, 6, 13, 20, 24 and 30 . Three to 5 gastropods were randomly taken from the experimental chamber, transferred to a sealed syringe with $50 \mathrm{ml}$ of seawater that was previously adjusted to the treatment DO level, and incubated for $30 \mathrm{~min}$. Syringes without gastropods served as negative controls. The initial and final oxygen concentrations were measured using an optical meter (TauTheta SOO-100). Respiration rate $\left(\mathrm{mg} \mathrm{O}_{2} \mathrm{~h}^{-1}\right)$ was then converted into its energy equivalent using a conversion factor of $13.98 \mathrm{~J} \mathrm{mg}^{-1} \mathrm{O}_{2}$ (Ivlev 1934).

Rate of energy lost to ammonia excretion. The rate of energy lost to ammonia excretion was measured on Days 3, 7, 14, 21, 25 and 31. All gastropods from the experimental chamber were transferred into a beaker with $500 \mathrm{ml}$ of seawater that was previously adjusted for the treatment DO level and incubated for $1 \mathrm{~h}$. Beakers without gastropods served as negative controls. The initial and final ammonia concentrations were measured by the phenate method (Eaton et al. 1995). The ammonia excretion rate was converted into energy equivalents using a conversion factor of $0.025 \mathrm{~J}$ $\mu^{-1} \mathrm{NH}_{4}-\mathrm{N}$ (Elliott \& Davison 1975).

Scope for growth. The SfG was calculated using the energy balance equation as follows (Winberg 1960):

$$
\mathrm{SfG}=A b-(R+U)
$$

with SfG on Day $[x-(x+2)], A b=$ Rate of energy intake from food obtained on experimental Day $x, R=$ rate of energy lost to respiration obtained on experimental Day $(x+1)$, and $U=$ rate of energy lost to ammonia excretion obtained on experimental Day $(x+2)$. For example, the SfG on Days 1 to 3 was calculated using the $A b$ on Day 1, R on Day 2 and U on Day 3.

Statistical analysis. The data were checked by Shapiro-Wilk normality test and equal variance test (Zar 1999). Cumulative mortalities were percentage data and arcsine transformed before analysis using 1-way ANOVA (Zar 1999). One measurement for each 
endpoint (rates of energy intake from food, lost to respiration and lost to excretion, and SfG) was obtained from each experimental chamber on an experimental day. For each endpoint, repeated measures of 2-way ANOVA were used to test the null hypothesis that there was no significant difference between different DO treatments at different experimental days. Twoway ANOVA (repeated measures) statistics were evaluated using the original degree of freedom when the assumption for the univariate tests held as verified by Mauchly's test $(\mathrm{p}>0.05)$. When the significance value of the Mauchly's test was $<0.05$, the degrees of freedom were adjusted to account for violation of the assumption using the Greenhouse-Geisser epsilon. Repeated measures of 1-way ANOVA were also used to test the difference of each endpoint at each level per experimental day, as well as for the DO treatment. If a significant difference was found by ANOVA, Tukey's multiple comparisons were used to identify the differences between the various experimental days or treatments.

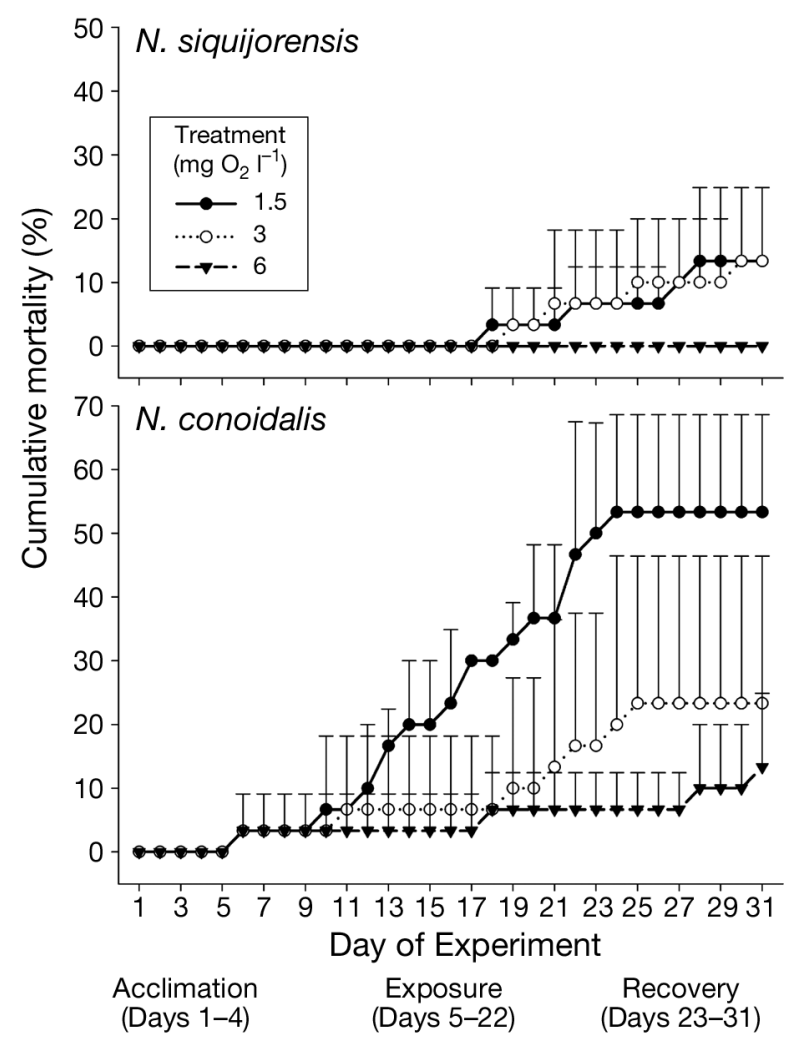

Fig. 2. Nassarius siquijorensis and N. conoidalis. Cumulative mortality. Means + SD of triplicates, each with 10 individuals. All treatments were exposed to a normoxic condition with dissolved oxygen (DO) level of $6 \mathrm{mg} \mathrm{O}_{2} \mathrm{l}^{-1}$ from Days 1 to 4 (acclimation). Subsequently, different treatments were exposed to different DO levels from Days 5 to 22 (exposure), and all were returned to the normoxic condition from Days 23 to 31 (recovery)

\section{RESULTS}

\section{Cumulative mortality}

All Nassarius siquijorensis individuals in the normoxic treatment (i.e. $6 \mathrm{mg} \mathrm{O}_{2} \mathrm{l}^{-1}$ ) survived until the end of the experiment (i.e. Day 31), while some individuals in the hypoxic treatments (i.e. 1.5 and $3 \mathrm{mg} \mathrm{O}_{2} \mathrm{l}^{-1}$ ) died on or after Day 18 (Fig. 2). On the last day of experiment, the means of cumulative mortality of the 1.5 and $3 \mathrm{mg} \mathrm{O}_{2} \mathrm{l}^{-1}$ treatments were both $13.3 \%$. There was no significant effect of the DO treatment on the cumulative mortality on Day 31 (ANOVA, p > 0.05).

Mortality of Nassarius conoidalis began on Day 6 (Fig. 2). On Day 31, the mean cumulative mortalities of the $1.5,3$ and $6 \mathrm{mg} \mathrm{O}_{2} \mathrm{l}^{-1}$ treatments were 53.3, 23.3 and $13.3 \%$, respectively, and these means were not statistically different (ANOVA, p > 0.05).

\section{Rate of energy intake from food}

The rate of energy intake of Nassarius siquijorensis was significantly affected by experimental day, DO treatment and their interaction (Fig. 3, Table 1a). At $1.5 \mathrm{mg}$ $\mathrm{O}_{2} \mathrm{l}^{-1}$, the rate on Day 29 was significantly higher than those on Days 5,12, 19 and 23; while at $6 \mathrm{mg} \mathrm{O}_{2} \mathrm{l}^{-1}$,

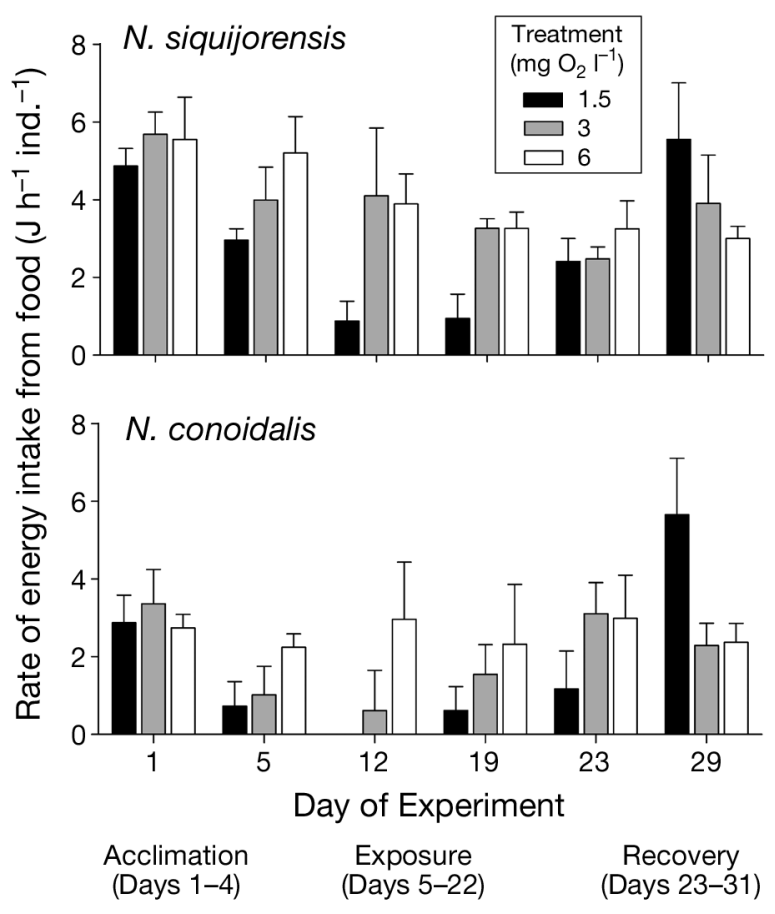

Fig. 3. Nassarius siquijorensis and $N$. conoidalis. Effects of dissolved oxygen (DO) level on rate of energy intake from food. Means + SD of triplicates, each with 3 to 10 individuals 
Table 1. Nassarius siquijorensis. Two-way ANOVA (repeated measures) showing the effects of dissolved oxygen (DO) level, day of experiment and their interaction on rates of energy (a) intake from food, (b) lost to respiration and (c) lost to excretion, as well as (d) scope for growth. Bold: significant

\begin{tabular}{|lrrrr|}
\hline Source of variation & df & MS & $F$ & $p$ \\
\hline (a) Rate of energy intake from food & & & \\
Day of experiment & 5 & 10.94 & 17.22 & $<\mathbf{0 . 0 0 1}$ \\
DO level & 2 & 6.437 & 8.240 & $\mathbf{0 . 0 3 8}$ \\
Day of experiment $\times$ DO level 10 & 3.762 & 5.140 & $<\mathbf{0 . 0 0 1}$ \\
Error & 20 & 0.732 & & \\
(b) Rate of energy lost to respiration & & & \\
Day of experiment & 5 & 0.257 & 10.64 & $<\mathbf{0 . 0 0 1}$ \\
DO & 2 & 0.650 & 14.63 & $\mathbf{0 . 0 1 4}$ \\
Day of experiment $\times$ DO level 10 & 0.127 & 5.810 & $<\mathbf{0 . 0 0 1}$ \\
Error & 20 & 0.022 & & \\
(c) Rate of energy lost to excretion & & & \\
Day of experiment & 1.755 & 0.029 & 20.17 & $<\mathbf{0 . 0 0 1}$ \\
DO level & 2 & 0.001 & 0.398 & 0.696 \\
Day of experiment $\times$ DO level3.510 & 0.009 & 7.249 & $\mathbf{0 . 0 0 6}$ \\
Error & 20 & 0.001 & & \\
(d) Scope for growth & & & & \\
Day of experiment & 5 & 8.757 & 14.79 & $<\mathbf{0 . 0 0 1}$ \\
DO level & 2 & 3.408 & 5.939 & 0.063 \\
Day of experiment $\times$ DO level 10 & 2.756 & 3.691 & $\mathbf{0 . 0 0 6}$ \\
Error & 20 & 0.747 & & \\
\hline
\end{tabular}

the rates on Days 1 and 5 were significantly higher than those on Days 19, 23 and 29 (Table 2a). During the normoxic acclimation (Day 1), early exposure (Day 5) and recovery period (Days 23 and 29), there was no significant difference in the rate between different DO treatments (Table 3a). However, during the mid and late exposure period (Days 12 and 19), the DO level significantly affected the rate of energy intake. When compared with the normoxic control, $1.5 \mathrm{mg} \mathrm{O}_{2} \mathrm{l}^{-1}$ treatment reduced the rates by 78 and $71 \%$ on Days 12 and 19 , respectively.

The rate of energy intake of Nassarius conoidalis was affected significantly by the experimental day as well as the interaction between the experimental day and the DO treatment (Fig. 3, Table 4a). At 1.5 and 3 $\mathrm{mg} \mathrm{O}_{2} \mathrm{l}^{-1}$, the rates were the highest on Day 29 and Day 1 , respectively (Table 5a). Furthermore, on Days $1,5,12,19$ and 23, the rates of energy intake from food did not differ significantly between the $3 \mathrm{DO}$ levels (Table 6a). However, on Day 29, N. conoidalis that had been exposed to $1.5 \mathrm{mg} \mathrm{O}_{2} \mathrm{l}^{-1}$ had a rate that was more than double that of those which had been exposed to 3 and $6 \mathrm{mg} \mathrm{O} \mathrm{I}^{-1}$.

\section{Rate of energy lost to respiration}

The rate of energy lost to respiration in Nassarius siquijorensis was affected significantly by experimental day, DO level and their interaction (Fig. 4, Table $1 b)$. At $1.5 \mathrm{mg} \mathrm{O}_{2} \mathrm{l}^{-1}$, the rate on Day 2 was significantly higher than those on Days 6, 13, 20, 24 and 30 (Table 2b). Moreover, during the acclimation and recovery periods, there was no significant difference in the rate of energy lost to respiration among the DO treatments (Table 3b: Days 2, 24 and 30). However, the $1.5 \mathrm{mg} \mathrm{O}_{2} \mathrm{l}^{-1}$ treatment significantly reduced the rate when compared with the normoxic control during the exposure period (Table 3b: Days 6, 13 and 20).

Table 2. Nassarius siquijorensis. One-way ANOVA (repeated measures) and Tukey's tests showing the effects of day of experiment on rates of energy (a) intake from food, (b) lost to respiration and (c) lost to excretion, as well as (d) scope for growth at each level of dissolved oxygen (DO). Row values are arranged from lowest to highest value; same row values with same letters = statistically indistinguishable. Bold: significant

\begin{tabular}{|c|c|c|c|c|c|c|c|c|c|c|}
\hline \multirow{2}{*}{$\begin{array}{l}\begin{array}{l}\text { DO level } \\
\left(\mathrm{mg} \mathrm{O}_{2} \mathrm{l}^{-1}\right)\end{array} \\
\text { (a) Rate of }\end{array}$} & \multirow{2}{*}{$\begin{array}{l}\text { MS effect } \\
\text { energy intak }\end{array}$} & \multirow{2}{*}{$\begin{array}{l}\text { MS error } \\
\text { from food }\end{array}$} & \multirow[t]{2}{*}{$F_{5,10}$} & \multirow[t]{2}{*}{$\mathrm{p}$} & \multicolumn{6}{|c|}{$\begin{array}{c}\text { Tukey's test } \\
\text { Day of experiment }\end{array}$} \\
\hline & & & & & & & & & & \\
\hline 1.5 & 11.47 & 0.638 & 17.96 & $<0.001$ & $29^{\mathrm{a}}$ & $1^{\mathrm{ab}}$ & $5^{\text {bc }}$ & $23^{\mathrm{bc}}$ & $19^{\mathrm{bc}}$ & $12^{\mathrm{bc}}$ \\
\hline 3 & 3.405 & 1.033 & 3.296 & 0.051 & 1 & 12 & 5 & 29 & 19 & 23 \\
\hline 6 & 3.594 & 0.428 & 8.404 & 0.020 & $1^{\mathrm{a}}$ & $5^{\mathrm{a}}$ & $12^{\mathrm{ab}}$ & $19^{\mathrm{b}}$ & $23^{\mathrm{b}}$ & $29^{\mathrm{b}}$ \\
\hline \multicolumn{11}{|c|}{ (b) Rate of energy lost to respiration } \\
\hline 1.5 & 0.361 & 0.017 & 21.57 & $<0.001$ & $2^{\mathrm{a}}$ & $30^{\mathrm{ab}}$ & $24^{\mathrm{bc}}$ & $6^{\mathrm{cd}}$ & $20^{\mathrm{d}}$ & $13^{\mathrm{d}}$ \\
\hline 3 & 0.114 & 0.040 & 3.371 & 0.063 & 2 & 24 & 6 & 30 & 20 & 13 \\
\hline 6 & 0.036 & 0.017 & 2.107 & 0.148 & 20 & 2 & 6 & 13 & 24 & 30 \\
\hline \multicolumn{11}{|c|}{ (c) Rate of energy lost to excretion } \\
\hline 1.5 & 0.012 & 0.001 & 26.93 & $<0.001$ & $25^{\mathrm{a}}$ & $31^{\mathrm{a}}$ & $3^{\mathrm{b}}$ & $7^{b}$ & $21^{\mathrm{b}}$ & $14^{\mathrm{b}}$ \\
\hline 3 & 0.004 & 0.001 & 4.746 & 0.018 & $31^{\mathrm{a}}$ & $25^{\mathrm{ab}}$ & $3^{\mathrm{ab}}$ & $7^{\mathrm{ab}}$ & $14^{\mathrm{ab}}$ & $21^{\mathrm{b}}$ \\
\hline 6 & 0.001 & 0.001 & 0.578 & 0.717 & 7 & 3 & 25 & 31 & 21 & 14 \\
\hline \multicolumn{11}{|c|}{ (d) Scope for growth } \\
\hline 1.5 & 8.140 & 0.667 & 12.21 & $<0.001$ & $29-31^{\mathrm{a}}$ & $1-3^{\mathrm{ab}}$ & $5-7^{\mathrm{abc}}$ & $23-25^{\mathrm{bc}}$ & $12-14^{\mathrm{c}}$ & $19-21^{c}$ \\
\hline 3 & 2.844 & 1.013 & 2.807 & 0.077 & $1-3$ & $12-14$ & $5-7$ & $29-31$ & $23-25$ & $19-21$ \\
\hline 6 & 3.285 & 0.406 & 8.098 & 0.003 & $1-3^{a}$ & $5-7^{a}$ & $12-14^{\mathrm{ab}}$ & $23-25^{b}$ & $29-31^{b}$ & $19-21^{b}$ \\
\hline
\end{tabular}


Table 3. Nassarius siquijorensis. One-way ANOVA (repeated measures) and Tukey's tests showing the effects of dissolved oxygen (DO) level on rates of energy (a) intake from food, (b) lost to respiration and (c) lost to excretion, as well as (d) scope for growth at each level of the day of experiment. Row values are arranged from lowest to highest value; same row values with same letters = statistically indistinguishable. Bold: significant

\begin{tabular}{|c|c|c|c|c|c|c|c|}
\hline $\begin{array}{l}\text { Day of } \\
\text { experiment }\end{array}$ & MS effect & MS error & $F_{2,4}$ & $\mathrm{p}$ & \multicolumn{3}{|c|}{$\begin{array}{c}\text { Tukey's test } \\
\text { DO level }\left(\mathrm{mg} \mathrm{O}_{2} \mathrm{l}^{-1}\right.\end{array}$} \\
\hline \multicolumn{8}{|c|}{ (a) Rate of energy intake from food } \\
\hline 1 & 0.576 & 0.665 & 0.866 & 0.487 & 3 & 6 & 1.5 \\
\hline 5 & 3.795 & 0.810 & 4.684 & 0.090 & 6 & 3 & 1.5 \\
\hline 12 & 9.770 & 1.213 & 8.054 & 0.040 & $3^{\mathrm{a}}$ & $6^{\mathrm{ab}}$ & $1.5^{\mathrm{b}}$ \\
\hline 19 & 5.401 & 0.274 & 19.71 & 0.008 & $3^{\mathrm{a}}$ & $6^{\mathrm{a}}$ & $1.5^{\mathrm{b}}$ \\
\hline 23 & 0.655 & 0.434 & 1.509 & 0.325 & 6 & 3 & 1.5 \\
\hline 29 & 5.051 & 1.044 & 4.838 & 0.086 & 1.5 & 3 & 6 \\
\hline \multicolumn{8}{|c|}{ (b) Rate of energy lost to respiration } \\
\hline 2 & 0.014 & 0.073 & 0.190 & 0.834 & 3 & 1.5 & 6 \\
\hline 6 & 0.335 & 0.001 & 37.64 & 0.003 & $6^{\mathrm{a}}$ & $3^{\mathrm{b}}$ & $1.5^{\mathrm{c}}$ \\
\hline 13 & 0.434 & 0.015 & 29.86 & 0.004 & $6^{\mathrm{a}}$ & $3^{\mathrm{b}}$ & $1.5^{\mathrm{c}}$ \\
\hline 20 & 0.452 & 0.035 & 13.03 & 0.018 & $6^{a}$ & $3^{\mathrm{ab}}$ & $1.5^{\mathrm{b}}$ \\
\hline 24 & 0.035 & 0.012 & 2.925 & 0.165 & 1.5 & 3 & 6 \\
\hline 30 & 0.015 & 0.011 & 1.405 & 0.345 & 1.5 & 6 & 3 \\
\hline \multicolumn{8}{|c|}{ (c) Rate of energy lost to excretion } \\
\hline 3 & 0.001 & 0.001 & 7.190 & 0.056 & 6 & 1.5 & 3 \\
\hline 7 & 0.002 & 0.001 & 117.8 & $<0.001$ & $6^{a}$ & $3^{b}$ & $1.5^{\mathrm{c}}$ \\
\hline 14 & 0.001 & 0.001 & 68.89 & $<0.001$ & $6^{\mathrm{a}}$ & $3^{b}$ & $1.5^{\mathrm{c}}$ \\
\hline 21 & 0.001 & 0.001 & 78.98 & $<0.001$ & $6^{a}$ & $3^{b}$ & $1.5^{\mathrm{c}}$ \\
\hline 25 & 0.007 & 0.001 & 9.731 & 0.029 & $1.5^{\mathrm{a}}$ & $3^{\mathrm{ab}}$ & $6^{\mathrm{b}}$ \\
\hline 31 & 0.005 & 0.002 & 2.643 & 0.186 & 1.5 & 3 & 6 \\
\hline \multicolumn{8}{|c|}{ (d) Scope for growth } \\
\hline $1-3$ & 0.617 & 0.628 & 0.983 & 0.449 & 3 & 6 & 1.5 \\
\hline $5-7$ & 1.768 & 0.818 & 2.161 & 0.231 & 6 & 3 & 1.5 \\
\hline $12-14$ & 6.578 & 1.023 & 6.432 & 0.044 & $3^{a}$ & $6^{\mathrm{ab}}$ & $1.5^{\mathrm{b}}$ \\
\hline $19-21$ & 3.140 & 0.375 & 8.365 & 0.037 & $3^{a}$ & $6^{\mathrm{ab}}$ & $1.5^{\mathrm{b}}$ \\
\hline $23-25$ & 0.520 & 0.345 & 1.504 & 0.326 & 6 & 3 & 1.5 \\
\hline $29-31$ & 4.563 & 1.117 & 4.085 & 0.108 & 1.5 & 3 & 6 \\
\hline
\end{tabular}

The rate of energy lost to respiration for Nassarius conoidalis was affected significantly by experimental day as well as the interaction between experimental day and DO treatment (Fig. 4, Table 4b). At $1.5 \mathrm{mg}$ $\mathrm{O}_{2} \mathrm{l}^{-1}$, the rates on Days 24 and 30 were significantly higher than those on Days 6, 13 and 20 (Table 5b). Furthermore, the rate of $1.5 \mathrm{mg} \mathrm{O} \mathrm{O}^{-1}$ treatment was the lowest among treatments during the exposure period (Table 6b: Days 6, 13 and 20), but it was the highest during the recovery period (Table 6b: Days 24 and 30). However, the differences between the DO treatments were only statistically significant on Days 6 and 24.

\section{Rate of energy lost to ammonia excretion}

There were significant effects of experimental day and interactive effects of experimental day and DO treatments on the rate of energy lost to ammonia excretion in Nassarius siquijorensis (Fig. 5, Table 1c). At 1.5 and $3 \mathrm{mg} \mathrm{O}_{2} \mathrm{l}^{-1}$, the rates were the highest during the recovery period followed by the acclimation period and were the lowest during the exposure period (Table 2c). At $1.5 \mathrm{mg} \mathrm{O}_{2} \mathrm{l}^{-1}$, the rates on Days 25 and 31 were significantly higher than those on Days 3, 7, 14 and 21. However, at $3 \mathrm{mg} \mathrm{O}_{2} \mathrm{l}^{-1}$, the rates were significantly different only between Days 31 and 21. Furthermore, during the acclimation and late recovery periods, there was no significant difference in the rate among the DO treatments (Table 3c: Days 3 and 31). Nevertheless, during the exposure period, the rates of the $1.5 \mathrm{mg} \mathrm{O}_{2} \mathrm{l}^{-1}$ treatment were significantly reduced compared with the respective rates of the 3 mg $\mathrm{O}_{2} \mathrm{l}^{-1}$ treatment, which were, in turn, significantly lower than that of the normoxic control (Table 3c: Days 7, 14 and 21).

The rate of energy lost to excretion of Nassarius conoidalis was affected significantly by experimental day, DO level and their interaction (Fig. 5, Table 4c). At 1.5 and $3 \mathrm{mg} \mathrm{O}_{2} \mathrm{l}^{-1}$, the rates during the exposure period (on Days 7 and 14) were significantly lower than on Day 31 (Table 5c). Furthermore, on Days 3, 21 and 31, the rates did not differ significantly between the 3 DO levels (Table 6c). The $1.5 \mathrm{mg} \mathrm{O}_{2} \mathrm{l}^{-1}$ treatment significantly reduced the rate compared with the normoxic control on both Day 7 and 14.

\section{Scope for growth}

There were significant effects of experimental day and the interaction between the experimental day and the DO treatment on SfG of Nassarius siquijorensis (Fig. 6, Table 1d). At $1.5 \mathrm{mg} \mathrm{O}_{2} \mathrm{l}^{-1}$, SfG on Days 12-14 and 19-21 were significantly lower than those on Days 1-3 and 29-31, while at $6 \mathrm{mg} \mathrm{O}_{2} \mathrm{l}^{-1}$, SfG on Days 19-21, 23-25 and 29-31 were significantly lower than those on Days 1-3 and 5-7 (Table 2d). Furthermore, during the mid and late exposure period, SfGs of the $1.5 \mathrm{mg} \mathrm{O}_{2} \mathrm{l}^{-1}$ treatments were $\sim 98 \%$ lower than those of the 3 and $6 \mathrm{mg} \mathrm{O}_{2} \mathrm{l}^{-1}$ treatments, and the differences in SfG were statistically significant between the rates at 1.5 and $3 \mathrm{mg} \mathrm{O}_{2} \mathrm{l}^{-1}$ (Table 3d: Day 12-14 and 1-21). There was no significant difference in SfG among the DO treatments on other experimental days. 
Table 4. Nassarius conoidalis. Two-way ANOVA (repeated measures) showing the effects of dissolved oxygen (DO) level, day of experiment and their interaction on rates of energy (a) intake from food, (b) lost to respiration and (c) lost to excretion, as well as (d) scope for growth

\begin{tabular}{|c|c|c|c|c|}
\hline Source of variation & df & MS & $F$ & $\mathrm{p}$ \\
\hline \multicolumn{5}{|l|}{ (a) Rate of energy intake from food } \\
\hline Day of experiment & 5 & 8.047 & 10.01 & 0.001 \\
\hline DO level & 2 & 2.957 & 2.089 & 0.239 \\
\hline Day of experiment $\times$ DO level 1 & 10 & 4.684 & 6.151 & $<0.001$ \\
\hline Error & 20 & 0.762 & & \\
\hline \multicolumn{5}{|l|}{ (b) Rate of energy lost to respiration } \\
\hline Day of experiment & 5 & 0.345 & 6.615 & 0.006 \\
\hline DO & 2 & 0.025 & 0.389 & 0.701 \\
\hline Day of experiment $\times$ DO level 1 & 10 & 0.145 & 9.456 & $<0.001$ \\
\hline Error & 20 & 0.015 & & \\
\hline \multicolumn{5}{|l|}{ (c) Rate of energy lost to excretion } \\
\hline Day of experiment & 5 & 0.007 & 18.65 & $<0.001$ \\
\hline DO level & 2 & 0.003 & 9.465 & 0.030 \\
\hline Day of experiment $\times$ DO level 1 & 10 & 0.003 & 7.654 & $<0.001$ \\
\hline Error & 20 & $<0.001$ & & \\
\hline \multicolumn{5}{|l|}{ (d) Scope for growth } \\
\hline Day of experiment & 5 & 5.851 & 5.200 & 0.013 \\
\hline DO level & 2 & 3.285 & 2.191 & 0.228 \\
\hline Day of experiment $\times$ DO level 1 & 10 & 4.331 & 5.655 & $<0.001$ \\
\hline Error & 20 & 0.766 & & \\
\hline
\end{tabular}

SfG of Nassarius conoidalis was significantly affected by experimental day and the interaction between the experimental day and the DO treatment (Fig.6, Table 4d). At 1.5 and $3 \mathrm{mg} \mathrm{O}_{2} \mathrm{l}^{-1}$, SfG was the highest on Days 29 to 31 and 1 to 3 , respectively

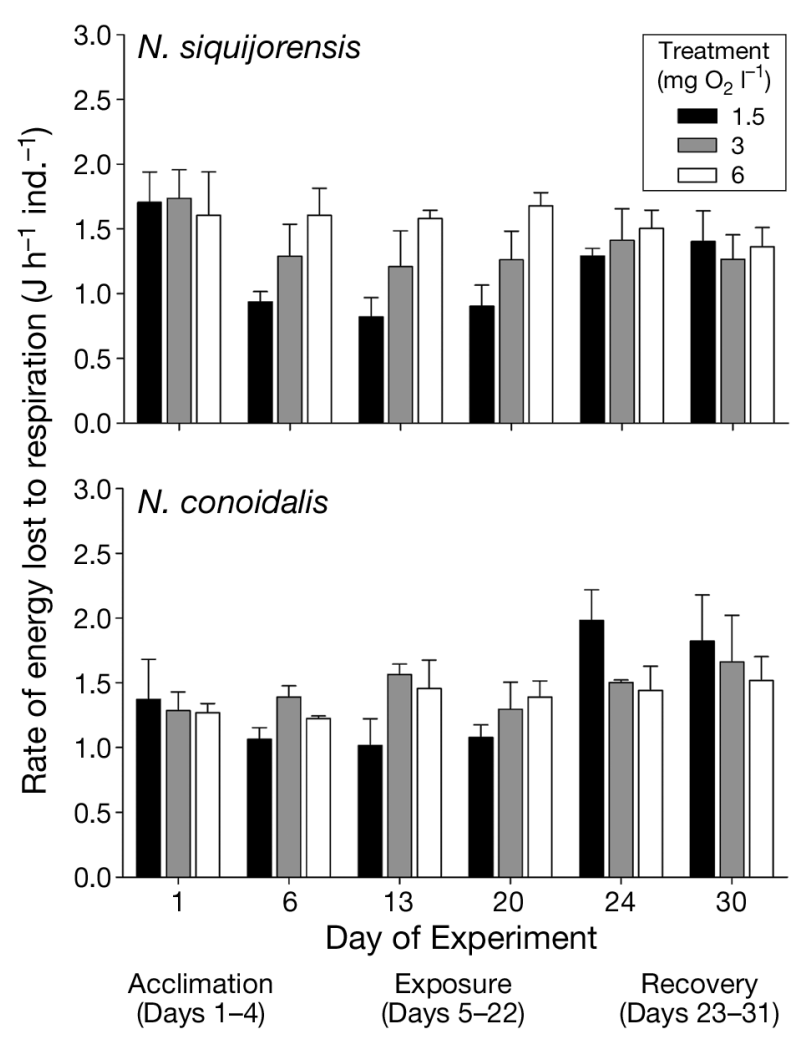

Fig. 4. Nassarius siquijorensis and $N$. conoidalis. Rate of energy lost to respiration. Means + SD of triplicates, each with 3 to 5 individuals

(Table 5d). Furthermore, the DO treatment did not affect significantly the SfG on any of the experimental days, except Days 29 to 31 (Table 6d). During the

Table 5. Nassarius conoidalis. One-way ANOVA (repeated measures) and Tukey's tests showing the effects of day of experiment on rates of energy (a) intake from food, (b) lost to respiration and (c) lost to excretion, as well as (d) scope for growth at each level of dissolved oxygen (DO). Row values are arranged from lowest to highest value; same row values with same letters = statistically indistinguishable. Bold: significant

\begin{tabular}{|c|c|c|c|c|c|c|c|c|c|c|}
\hline $\begin{array}{l}\text { DO level } \\
\left(\mathrm{mg} \mathrm{O}_{2} \mathrm{l}^{-1}\right)\end{array}$ & MS effect & MS error & $F_{5,10}$ & $\mathrm{p}$ & & & $\begin{array}{l}\text { Tukey' } \\
\text { Day of exp }\end{array}$ & $\begin{array}{l}\text { test } \\
\text { eriment }\end{array}$ & & \\
\hline \multicolumn{11}{|c|}{ (a) Rate of energy intake from food } \\
\hline 1.5 & 13.31 & 0.841 & 15.83 & $<0.001$ & $29^{\mathrm{a}}$ & $1^{\mathrm{b}}$ & $23^{\mathrm{bc}}$ & $5^{\mathrm{bc}}$ & $19^{\mathrm{bc}}$ & $12^{\mathrm{c}}$ \\
\hline 3 & 3.764 & 0.632 & 5.954 & 0.008 & $1^{\mathrm{a}}$ & $23^{\mathrm{ab}}$ & $29^{\mathrm{abc}}$ & $19^{\mathrm{abc}}$ & $5^{\mathrm{bc}}$ & $12^{\mathrm{c}}$ \\
\hline 6 & 0.338 & 0.854 & 0.396 & 0.841 & 29 & 23 & 12 & 1 & 19 & 5 \\
\hline \multicolumn{11}{|c|}{ (b) Rate of energy lost to respiration } \\
\hline 1.5 & 0.527 & 0.040 & 13.14 & $<0.001$ & $24^{\mathrm{a}}$ & $30^{\mathrm{ab}}$ & $2^{\mathrm{bc}}$ & $20^{\mathrm{c}}$ & $6^{\mathrm{c}}$ & $13^{\mathrm{c}}$ \\
\hline 3 & 0.069 & 0.029 & 2.372 & 0.115 & 30 & 13 & 24 & 6 & 20 & 2 \\
\hline 6 & 0.039 & 0.014 & 2.862 & 0.074 & 30 & 13 & 24 & 20 & 2 & 6 \\
\hline \multicolumn{11}{|c|}{ (c) Rate of energy lost to excretion } \\
\hline 1.5 & 0.010 & 0.001 & 12.64 & $<0.001$ & $31^{\mathrm{a}}$ & $25^{\mathrm{a}}$ & $21^{\mathrm{ab}}$ & $3^{\mathrm{b}}$ & $14^{\mathrm{b}}$ & $7^{\mathrm{b}}$ \\
\hline 3 & 0.002 & 0.001 & 19.38 & $<0.001$ & $31^{\mathrm{a}}$ & $3^{\mathrm{b}}$ & $25^{\mathrm{bc}}$ & $21^{\mathrm{bcd}}$ & $7^{\mathrm{cd}}$ & $14^{\mathrm{d}}$ \\
\hline 6 & 0.001 & 0.001 & 0.669 & 0.656 & 21 & 31 & 3 & 25 & 7 & 14 \\
\hline \multicolumn{11}{|c|}{ (d) Scope for growth } \\
\hline 1.5 & 10.32 & 1.170 & 8.816 & 0.002 & $29-31^{a}$ & $1-3^{\mathrm{ab}}$ & $5-7^{b}$ & $19-21^{\mathrm{b}}$ & $23-25^{\mathrm{b}}$ & $12-14^{\mathrm{b}}$ \\
\hline 3 & 3.881 & 0.715 & 5.427 & 0.011 & $1-3^{a}$ & $23-25^{\mathrm{ab}}$ & $29-31^{\mathrm{abc}}$ & $19-21^{\mathrm{abc}}$ & $5-7^{\mathrm{bc}}$ & $12-14^{c}$ \\
\hline 6 & 0.315 & 0.772 & 0.409 & 0.832 & $23-25$ & $12-14$ & $1-3$ & $5-7$ & $19-21$ & $29-31$ \\
\hline
\end{tabular}


Table 6. Nassarius conoidalis. One-way ANOVA (repeated measures) and Tukey's tests showing the effects of dissolved oxygen (DO) level on energy rates (a) from food intake, (b) lost to respiration and (c) lost to excretion, as well as (d) scope for growth at each level of the day of experiment. Row values are arranged from lowest to highest value; same row values with same letters = statistically indistinguishable

\begin{tabular}{|c|c|c|c|c|c|c|c|}
\hline $\begin{array}{l}\text { Day of } \\
\text { experiment }\end{array}$ & MS effect & MS error & $F_{2,4}$ & $\mathrm{p}$ & \multicolumn{3}{|c|}{$\begin{array}{c}\text { Tukey's test } \\
\text { DO level }\left(\mathrm{mg} \mathrm{O}_{2} \mathrm{l}^{-1}\right)\end{array}$} \\
\hline \multicolumn{8}{|c|}{ (a) Rate of energy intake from food } \\
\hline 1 & 0.320 & 0.488 & 0.656 & 0.567 & 3 & 1.5 & 6 \\
\hline 5 & 1.939 & 0.526 & 3.687 & 0.124 & 6 & 3 & 1.5 \\
\hline 12 & 7.353 & 1.432 & 5.136 & 0.079 & 6 & 3 & 1.5 \\
\hline 19 & 2.190 & 1.244 & 1.761 & 0.283 & 6 & 3 & 1.5 \\
\hline 23 & 3.531 & 1.180 & 2.993 & 0.160 & 3 & 6 & 1.5 \\
\hline 29 & 11.05 & 0.354 & 31.21 & 0.004 & $1.5^{\mathrm{a}}$ & $6^{\mathrm{b}}$ & $3^{\mathrm{b}}$ \\
\hline \multicolumn{8}{|c|}{ (b) Rate of energy lost to respiration } \\
\hline 2 & 0.009 & 0.038 & 0.248 & 0.791 & 3 & 1.5 & 6 \\
\hline 6 & 0.079 & 0.007 & 11.51 & 0.022 & $3^{\mathrm{a}}$ & $6^{\mathrm{ab}}$ & $1.5^{\mathrm{b}}$ \\
\hline 13 & 0.253 & 0.041 & 6.213 & 0.059 & 3 & 6 & 1.5 \\
\hline 20 & 0.077 & 0.021 & 3.599 & 0.128 & 6 & 3 & 1.5 \\
\hline 24 & 0.262 & 0.021 & 12.79 & 0.018 & $1.5^{\mathrm{a}}$ & $3^{\mathrm{b}}$ & $6^{\mathrm{b}}$ \\
\hline 30 & 0.069 & 0.013 & 5.413 & 0.073 & 1.5 & 3 & 6 \\
\hline \multicolumn{8}{|c|}{ (c) Rate of energy lost to excretion } \\
\hline 3 & 0.001 & 0.001 & 0.349 & 0.725 & 3 & 6 & 1.5 \\
\hline 7 & 0.001 & 0.001 & 11.42 & 0.022 & $6^{\mathrm{a}}$ & $3^{\mathrm{ab}}$ & $1.5^{\mathrm{b}}$ \\
\hline 14 & 0.001 & 0.001 & 22.84 & 0.006 & $6^{\mathrm{a}}$ & $1.5^{\mathrm{b}}$ & $3^{b}$ \\
\hline 21 & 0.001 & 0.001 & 2.747 & 0.178 & 1.5 & 6 & 3 \\
\hline 25 & 0.007 & 0.001 & 27.48 & 0.005 & $1.5^{\mathrm{a}}$ & $3^{\mathrm{b}}$ & $6^{\mathrm{b}}$ \\
\hline 31 & 0.007 & 0.001 & 5.833 & 0.065 & 1.5 & 3 & 6 \\
\hline \multicolumn{8}{|c|}{ (d) Scope for growth } \\
\hline $1-3$ & 0.342 & 0.774 & 0.442 & 0.671 & 3 & 1.5 & 6 \\
\hline $5-7$ & 1.806 & 0.485 & 3.728 & 0.122 & 6 & 3 & 1.5 \\
\hline $12-14$ & 6.072 & 1.148 & 5.290 & 0.075 & 6 & 1.5 & 3 \\
\hline $19-21$ & 1.486 & 1.302 & 1.141 & 0.405 & 6 & 3 & 1.5 \\
\hline $23-25$ & 6.093 & 1.192 & 5.113 & 0.079 & 3 & 6 & 1.5 \\
\hline $29-31$ & 9.139 & 0.429 & 21.30 & 0.007 & $1.5^{\mathrm{a}}$ & $6^{\mathrm{b}}$ & $3^{b}$ \\
\hline
\end{tabular}

whole exposure and early recovery periods, SfG of the $1.5 \mathrm{mg} \mathrm{O}_{2} \mathrm{l}^{-1}$ treatment had negative values, in contrast with the positive SfG of the normoxic control (Fig.6). SfG of the $3 \mathrm{mg} \mathrm{O}_{2} \mathrm{l}^{-1}$ treatment also had negative values during the early and mid exposure periods. However, when $N$. conoidalis from the $1.5 \mathrm{mg} \mathrm{O}_{2} \mathrm{l}^{-1}$ treatment entered the late recovery period, they showed a rebound in SfG that was 7 and 4.5-fold that of the 3 and $6 \mathrm{mg} \mathrm{O}$ $\mathrm{l}^{-1}$ treatments, respectively.

\section{DISCUSSION}

It was suggested that hypoxia reduces feeding in a variety of invertebrates, and it is likely that reduction in feeding is the main cause for growth impairment ( $\mathrm{Wu}$ 2002). The stronger hypoxia treatment significantly reduced the rate of energy intake for Nassarius siquijorensis after exposure for $\geq 8 \mathrm{~d}$ (Table $3 \mathrm{a}$ ). These findings are consistent with previous studies on the southern oyster drill Stramonita haemastoma, the lesser blue crab Callinectes similis and the blue crab $C$. sapidus. They all decreased their feeding rates after exposure to hypoxia for 28 d (Das \& Stickle 1993). Our results also showed that $N$. conoidalis stopped

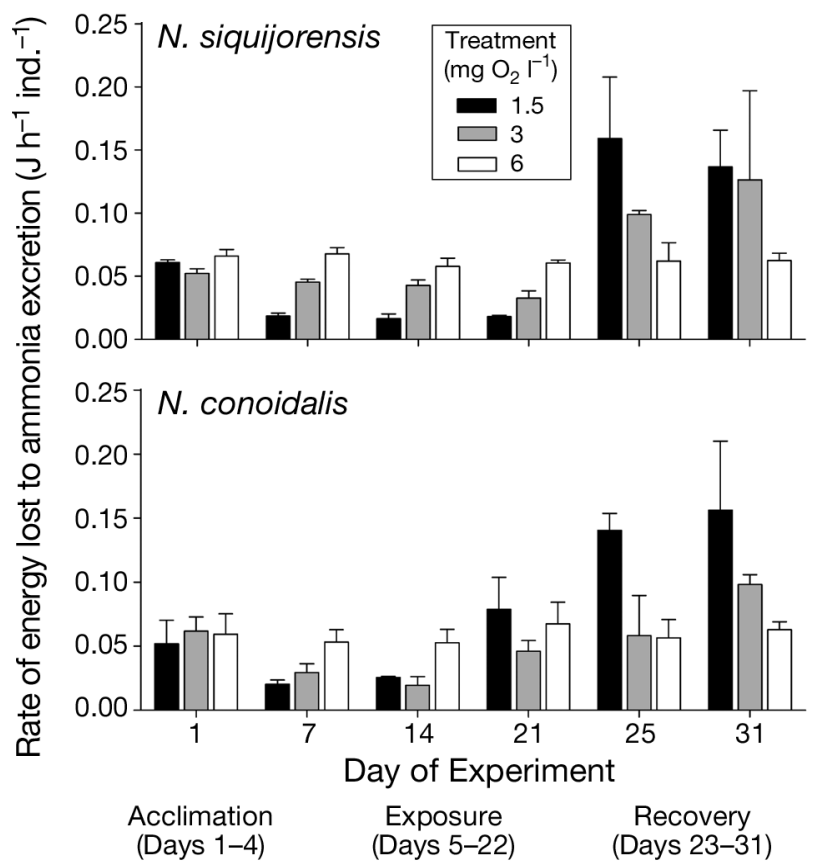

feeding at $1.5 \mathrm{mg} \mathrm{O}_{2} \mathrm{l}^{-1}$ after exposure for $\geq 8 \mathrm{~d}$ (Fig. 3). Similarly, the Norway lobster Nephrops norvegicus ceased feeding when held at $<2.8 \mathrm{mg} \mathrm{O}_{2} \mathrm{l}^{-1}$ for $3 \mathrm{wk}$ (Baden et al. 1990), and the annelid Loimina medusa stopped feeding after exposure to $<1 \mathrm{mg} \mathrm{O}_{2} \mathrm{l}^{-1}$ for $20 \mathrm{~h}$ (Llanso \& Diaz 1994). Nonetheless, $N$. conoidalis that had been exposed to $1.5 \mathrm{mg} \mathrm{O} \mathrm{O}^{-1}$ before being returned to normoxia demonstrated a significant increase in the rate of energy intake when compared with control (Table 6a: Day 29).

Nassarius siquijorensis reduced the rate of energy lost to respiration when exposed to $3 \mathrm{mg} \mathrm{O}_{2} \mathrm{l}^{-1}$ (Table 3b: Day 6, 13 and 20). This result agreed with a previous study that showed that $N$. siquijorensis could maintain its respiration rate only at $>3.55 \mathrm{mg} \mathrm{O}_{2} \mathrm{l}^{-1}$ (Cheung 1997). Moreover, N. conoidalis could main-

Fig. 5. Nassarius siquijorensis and $N$. conoidalis. Rate of energy lost to ammonia excretion. Means + SD of triplicates, each with 3 to 10 individuals 


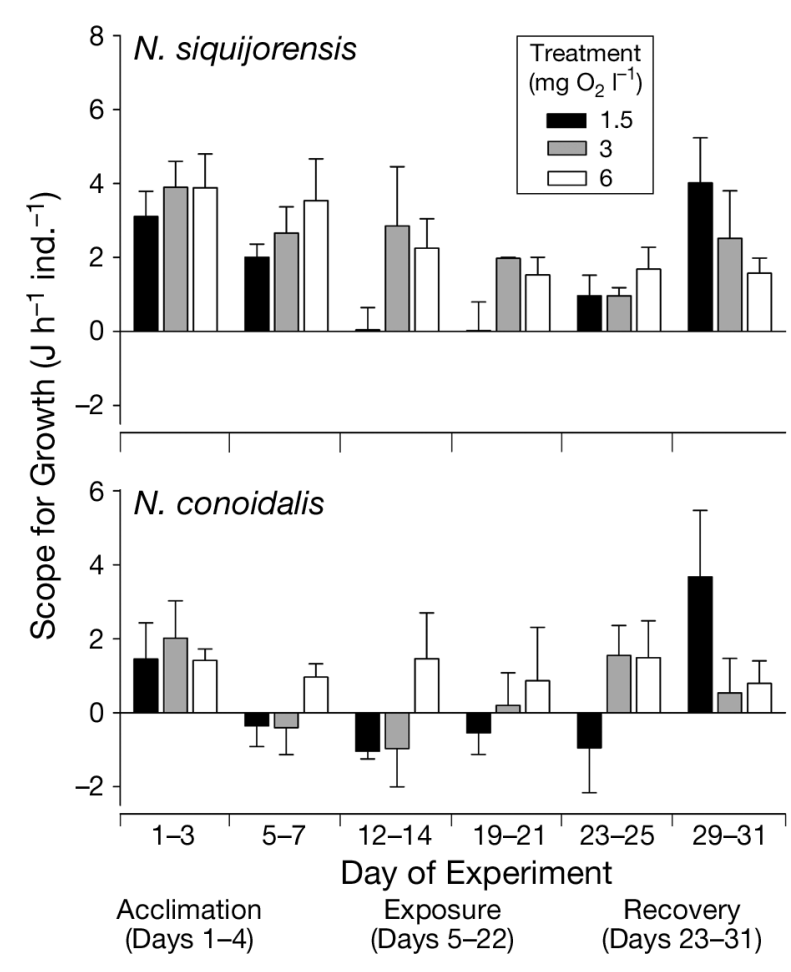

Fig. 6. Nassarius siquijorensis and N. conoidalis. Scope for growth (SfG). Means $+\mathrm{SD}$ of triplicates, each with 3 to 10 individuals. SfG on Day $(x$ to $x+2)$ was calculated using the rate of energy intake from food on Day $x$, rate of energy lost to respiration on Day $x+1$ and rate of energy lost to ammonia excretion on Day $x+2$

tain its respiration rate at $<3 \mathrm{mg} \mathrm{O}_{2} \mathrm{l}^{-1}$ (Table 6b: Day 6). It was suggested that being able to maintain respiration rate and, hence, foraging activity relatively independent of DO level may be an adaptation for marine scavengers (McMahon 1992). This oxy-regulatory capacity was also observed in other gastropods, such as the neogastropod Stramonita haemastoma, which had a stable respiration rate at $>4.5 \mathrm{mg} \mathrm{O}_{2} \mathrm{l}^{-1}$, but the rate decreased sharply beyond this threshold (McMahon 1992).

Significant reduction of SfG was observed in Nassarius siquijorensis after exposure to $1.5 \mathrm{mg} \mathrm{O}_{2} \mathrm{l}^{-1}$ during the mid and late exposure periods (Table 3d: Days 12-14 and 19-21). In contrast, a weaker hypoxia treatment $\left(3 \mathrm{mg} \mathrm{O}_{2} \mathrm{l}^{-1}\right)$ did not reduce the $\mathrm{SfG}$ for $N$. siquijorensis. Furthermore, exposure to $\leq 3 \mathrm{mg} \mathrm{O}_{2} \mathrm{l}^{-1}$ resulted in a negative SfG for $N$. conoidalis (except for the weaker hypoxia treatment on Days 19 to 21), in contrast with the positive SfG in the normoxic control and for N. siquijorensis at all tested DO levels (Fig. 6). A positive SfG means that energy is available for growth and reproduction, while a negative value means that the energy lost in respiration and excretion exceeds the organism's uptake from food, and the organism must use its own energy reserves to maintain basic life processes (Navarro et al. 2006).

The most surprising result here is the significant increase in SfG during the late recovery period of Nassarius conoidalis from the stronger hypoxia treatment (Table 6d: Days 19 to 31). The SfG of $N$. siquijorensis from the stronger hypoxia treatment was also 1.5 -fold higher than the control during the late recovery period (Fig. 6). We did not find published work that showed compensation in the physiology of marine invertebrates during normoxic recovery after exposure to hypoxia, although a suitable explanation remains to be found. It is untested, but possible, that the SfG increase in a normoxic recovery period may compensate for the earlier reduction during hypoxia and may enhance the survival of the individual in an environment with intermittently fluctuating DO levels.

This study suggests that SfG was a sensitive stress indicator for hypoxia. Evidently, changes in SfG were readily observed here, whereas no significant difference among treatments was found for the cumulative mortality (Fig. 2). The ability to predict ecological risk to higher organization levels (population, community and ecosystem levels) from observed responses at lower organization levels (molecular, biochemical and physiological responses) is of considerable practical importance, since this would provide a useful early warning system before the occurrence of significant environmental degradation. Our data, however, did not address the question of how well the use of SfG, as a hypoxic stress indicator, can extrapolate information regarding relevant ecological risks. Future experiments should be designed to address this question.

In the 1980s, Tolo Harbour, Hong Kong, was seriously polluted by agricultural wastes and domestic sewage, and hypoxia occurred from time to time in the bottom waters during summers as a result of thermal stratification, causing mass mortality of benthic species (Wu 1982). From 1978 to 1995, the relative abundance of Nassarius siquijorensis among all Nassarius species in the Harbour increased from 11.2 to $96.0 \%$ (Chan \& Morton 1997). Since 1996, the water quality has improved after implementation of pollution control measures commissioned by the Environmental Protection Department (EPD), Hong Kong SAR Government. Nonetheless, the monitoring data of EPD between 2003 and 2007 revealed that the bottom waters were affected by hypoxia and that the DO was $<3 \mathrm{mg} \mathrm{O}_{2} \mathrm{l}^{-1}$ for $\sim 10 \%$ of the summer time (EPD 2007). Furthermore, no $N$. conoidalis were found in the harbour in a recent survey (unpubl. data).

While Nassarius conoidalis stopped feeding at $1.5 \mathrm{mg}$ $\mathrm{O}_{2} \mathrm{l}^{-1}$ (Fig. 3) and had a negative $\mathrm{SfG}$ at $\leq 3 \mathrm{mg} \mathrm{O} \mathrm{I}^{-1}$ (Fig. 6), N. siquijorensis continued feeding and had a positive $\mathrm{SfG}$, even at $1.5 \mathrm{mg} \mathrm{O}_{2} \mathrm{l}^{-1}$. This suggested that 
$N$. siquijorensis was more tolerant to low DO and may well explain its dominance in Tolo Harbour, which has been affected by hypoxia over the past 30 yr. In coastal water, hypoxia may cause changes in species abundance and distribution and alter species community composition (Dauer 1993, Weisberg et al. 2008). Here, we suggest that hypoxia has eliminated the relatively sensitive $N$. conoidalis and replaced it with the conspecific $N$. siquijorensis.

Hypoxia caused by organic pollution is often associated with elevated levels of microbially generated hydrogen sulphide (Diaz \& Rosenberg 1995, Hagy et al. 2004). For example, the isopod Saduria entomon is able to synthesize haemocyanin to enhance oxygen uptake during hypoxia, but the synthesis is inhibited when the organism is also exposed to hydrogen sulphide (Hagerman \& Vismann 1993). Further research should focus on testing the interactions of hypoxia and hydrogen sulphide in factorial-design laboratory experiments. A clearer picture concerning the interactive effects could also be obtained by multivariate statistical analyses that determine the importance of these 2 confounding factors under field situations.

Acknowledgements. This manuscript benefited greatly from the comments and suggestions of 4 anonymous reviewers, especially those on how to structure the Introduction section, improve the writing and interpret the data. The work described in this paper was fully supported by a grant from the Research Grants Council of the Hong Kong Special Administrative Region, China (Project No. CityU 1401/06M).

\section{LITERATURE CITED}

Baden SP, Pihl L, Rosenberg R (1990) Effects of oxygen depletion on the ecology, blood physiology and fishery of the Norway lobster Nephrops norvegicus. Mar Ecol Prog Ser 67:141-155

Baillieul M, Selens M, Blust R (1996) Scope for growth and fitness of Daphnia magna in salinity-stressed conditions. Funct Ecol 10:227-233

Baillieul M, Smolders R, Blust R (2005) The effects of environmental stress on absolute and mass-specific scope for growth in Daphnia magna Strauss. Comp Biochem Physiol C 140:364-373

Beiras R, Camacho AP, Albentosa M (1994) Comparison of the scope for growth with the growth performance of Ostrea edulis seed reared at different food concentrations in an open flow system. Mar Biol 119:227-233

Britton JC, Morton B (1992) The ecology and feeding behaviour of Nassarius festivus (Prosobranchia: Nassariidae) from two Hong Kong bays. In: Morton B (ed) Proc 4th Int Mar Biol workshop: the marine flora and fauna of Hong Kong and Southern China, Hong Kong 1989. Hong Kong University Press, Hong Kong, p 395-415

Cernohorsky WO (1984) Systematics of the family Nassariidae (Mollusca: Gastropoda). Bull Auckland Inst Mus 14: 13-56

Chabot D, Dutil JD (1999) Reduced growth of Atlantic cod in non-lethal hypoxic conditions. J Fish Biol 55:472-491
Chan K, Morton B (1997) The tolerance of Hong Kong species of Nassariidae (Mollusca: Gastropoda) to anoxia. In: Morton B (ed) Proc 5th Int Mar Biol workshop: The marine flora and fauna of Hong Kong and Southern China, Hong Kong 1995. Hong Kong University Press, Hong Kong, p 489-502

Cheung SG (1997) Respiration studies of the subtidal Nassarius siquijorensis (Gastropoda: Nassariidae) from Hong Kong. In: Morton B (ed) Proc 5th Int Mar Biol workshop: The marine flora and fauna of Hong Kong and Southern China, Hong Kong 1995. Hong Kong University Press, Hong Kong, p 391-399

Conover RJ (1966) Assimilation of organic matter by zooplankton. Limnol Oceanogr 11:338-345

> Das T, Stickle WB (1993) Sensitivity of crabs Callinectes sapidus and $C$. similis and the gastropod Stramonita haemastoma to hypoxia and anoxia. Mar Ecol Prog Ser 98: 263-274

Dauer DM (1993) Biological criteria, environmental health and estuarine macrobenthic community structure. Mar Pollut Bull 26:249-257

Diaz RJ, Rosenberg R (1995) Marine benthic hypoxia: a review of its ecological effects and the behavioural responses of benthic macrofauna. Oceanogr Mar Biol Annu Rev 33:245-303

Diaz RJ, Rosenberg R (2008) Spreading dead zones and consequences for marine ecosystems. Science 321:926-929

Eaton DA, Clesceri SL, Arnold E (1995) Standard methods for examination of water and wastewater, 19th edn. Am Public Health Assoc, Washington DC

Elliott JM, Davison W (1975) Energy equivalents of oxygen consumption in animal energetics. Oecologia 19:195-201

EPD (2007) Annual marine water quality reports 2003-2007. Environmental Protection Department, Hong Kong SAR Government, Hong Kong

Forbes TL, Lopez GR (1990) The effect of food concentration, body size, and environmental oxygen tension on the growth of the deposit-feeding polychaete, Capitella species I. Limnol Oceanogr 35:1535-1544

Genoni GP, Pahi-Wohstl C (1991) Measurement of scope for growth in ascendency for short term assessment of community stress. Can J Fish Aquat Sci 48:968-974

Hagerman L, Vismann B (1993) Anaerobic metabolism, hypoxia and hydrogen sulphide in the brackish water isopod Saduria entomon (L.). Ophelia 38:1-11

Hagy J, Boynton W, Keefe C, Wood K (2004) Hypoxia in Chesapeake Bay, 1950-2001: long-term change in relation to nutrient loading and river flow. Estuar Coast 27:634-658

Harris JO, Maguire GB, Edwards SJ, Johns DR (1999) Low dissolved oxygen reduces growth rate and oxygen consumption rate of juvenile greenlip abalone, Haliotis laevigata Donovan. Aquaculture 174:265-278

Ivlev VS (1934) Eine Micromethode zur Bestimmung des Kaloriengehalts von Nährstoffen. Biochem Z 6:49-55

Levin LA (2003) Oxygen minimum zone benthos: adaptation and community response to hypoxia. Oceanogr Mar Biol Annu Rev 41:1-45

Liu JH, Morton B (1994) Food choice, detection, time spent feeding, consumption and the effects of starvation on a subtidal scavenger, Nassarius siquijorensis (Gastropoda: Nassariidae), from Hong Kong. In: Morton B (ed) Proc 3rd Int workshop on the malacofauna of Hong Kong and Southern China, Hong Kong 1992. Hong Kong University Press, Hong Kong, p 357-375

> Llanso RJ, Diaz RJ (1994) Tolerance to low dissolved oxygen by the tubicolous polychaete Loimia medusa. J Mar Biol Assoc UK 74:143-148 
Maltby L (1992) The use of physiological energetics of Gammarus pulex to assess toxicity: a study using artificial streams. Environ Toxicol Chem 11:79-85

Maltby L, Naylor C, Calow P (1990) Effect of stress on a freshwater benthic detritivore: scope for growth in Gammarus pulex. Ecotoxicol Environ Saf 19:285-291

McMahon RE (1992) Respiratory response to temperature and hypoxia in intertidal gastropods from the Texas coast of the Gulf of Mexico. In: Grahame J, Mill PJ, Reid DG (eds) Proc 3rd Int Symp on littorinid biology. Malacological Society of London, London, p 45-59

Morton B, Chan K (1999) Hunger rapidly overrides the risk of predation in the subtidal scavenger Nassarius siquijorensis (Gastropoda: Nassariidae): an energy budget and a comparison with the intertidal Nassarius festivus in Hong Kong. J Exp Mar Biol Ecol 240:213-228

Navarro JM, Urrutia GX, Carrasco C (2006) Scope for growth versus actual growth in the juvenile predatory gastropod Chorus giganteus. J Mar Biol Assoc UK 86:1423-1428

Nilsson H, Rosenberg R (1994) Hypoxic response of two marine benthic communities. Mar Ecol Prog Ser 115:209-217

Paerl HW (2006) Assessing and managing nutrient-enhanced eutrophication in estuarine and coastal waters: interactive effects of human and climatic perturbations. Ecol Eng 26: 40-54

Petersen JK, Pihl L (1995) Responses to hypoxia of plaice, Pleuronectes platessa, and dab, Limanda limanda, in the south-east Kattegat: distribution and growth. Environ Biol Fishes 43:311-321

Pihl L, Baden SP, Diaz RJ, Schaffner LC (1992) Hypoxiainduced structural changes in the diet of bottom-feeding fish and crustacea. Mar Biol 112:349-361

Roast SD, Widdows J, Jones MB (1999) Scope for growth of the estuarine mysid Neomysis integer (Peracardia: Mysidacea): effects of the organophosphate pesticide chlorpyrifos. Mar Ecol Prog Ser 191:233-241

Editorial responsibility: Hans Heinrich Janssen, Oldendorf/Luhe, Germany
Sobral P, Widdows J (1997) Influence of hypoxia and anoxia on the physiological responses of the clam Ruditapes decussatus from southern Portugal. Mar Biol 127:455-461

Taylor JC, Miller JM (2001) Physiological performance of juvenile southern flounder, Paralichthys lethostigma (Jordan \& Gilbert, 1884), in chronic and episodic hypoxia. J Exp Mar Biol Ecol 258:195-214

Vaquer-Sunyer R, Duarte CM (2008) Thresholds of hypoxia for marine biodiversity. Proc Natl Acad Sci USA 105: 15452-15457

- Wannamaker CM, Rice JA (2000) Effects of hypoxia on movements and behavior of selected estuarine organisms from the southeastern United States. J Exp Mar Biol Ecol 249: 145-163

Weisberg SB, Thompson B, Ranasinghe JA, Montagne DE and others (2008) The level of agreement among experts applying best professional judgment to assess the condition of benthic infaunal communities. Ecol Indic 8: 389-394

Winberg GG (1960) Rate of metabolism and food requirements of fishes. Fish Res Board Can Transl Ser 194:1-239

Wu RSS (1982) Periodic defaunation and recovery in a subtropical epibenthic community, in relation to organic pollution. J Exp Mar Biol Ecol 64:253-269

> Wu RSS (2002) Hypoxia: from molecular responses to ecosystem responses. Mar Pollut Bull 45:35-45

$>$ Wu RSS (2009) Effects of hypoxia on fish reproduction and development. Fish Physiol 27:79-141

> Wu RSS, Or YY (2005) Bioenergetics, growth and reproduction of amphipods are affected by moderately low oxygen regimes. Mar Ecol Prog Ser 297:215-223

> Wu RSS, Lam PKS, Wan KL (2002) Tolerance to, and avoidance of, hypoxia by the penaeid shrimp (Metapenaeus ensis). Environ Pollut 118:351-355

Zar JH (1999) Biostatistical analysis, 4th edn. Prentice Hall, Englewood Cliffs, NJ

Submitted: March 26, 2010; Accepted: February 24, 2011

Proofs received from author(s): May 5, 2011 